\title{
ANALISIS PENGARUH PENERAPAN SISTEM INFORMASI MANAJEMEN DIKLAT DAN KOMPETENSI PEGAWAI TERHADAP KINERJA PEGAWAI (STUDI KASUS POLITEKNIK PELAYARAN SORONG)
}

\author{
Oleh \\ I Made Mariasa ${ }^{1}$; Muhammad Fahrul ${ }^{2}$; Ryan P Sumarta ${ }^{3}$; Kukuh Bayu Aji ${ }^{4}$ \\ 1,2,3,4 Politeknik Pelayaran Sorong
}

\begin{abstract}
Abstrak
Kinerja pegawai merupakan salah satu faktor untuk meningkatkan pelayanan pada sebuah institusi. Penelitian ini bertujuan untuk melakukan analisis terhadap pengaruh penerapan sistem informasi manajemen diklat dan kompetensi pegawai terhadap kinerja pegawai pada Politeknik Pelayaran Sorong. Pada penelitian ini, analisis data menggunakan metode analisis regresi linier berganda untuk mengukur pengaruh antara lebih dari satu variabel prediktor (variabel bebas) terhadap variabel terikat yang dioleh dengan SPSS berdasarkan kerangka konseptual dan hipotesis yang telah ditentukan untuk membuktikan sebagian hipotesis penelitian. Hasil pengujian melalui analisis regresi (uji beta) terhadap variabel dependen (y) dan independent (X1) dan (X2) tersebut didapatkan bahwa kompetensi pegawai (X2) memberikan pengaruh yang lebih dominan terhadap kinerja pegawai (y) dibandingkan dengan penerapan sistem informasi manajemen (X1). Hal ini didukung dengan data nilai hitung kompetensi pegawai (X2) yang lebih tinggi dibandingkan penerapan sistem informasi manajemen (X1). Namun kombinasi keduanya mampu memberikan kontribusi yang cukup besar terhadap kinerja pegawai.
\end{abstract}

Kata kunci: Analisis Pengaruh Penerapan Sistem Informasi, Manajemen Diklat, Analisis Kinerja Pegawai

\section{Abstract}

Employee performance is one of the factors to improve services at an institution. This study aims to analyze the effect of implementing a training management information system and employee 
competence on employee performance at the Sorong Shipping Polytechnic. In this study, data analysis used multiple linear regression analysis method to measure the effect of more than one predictor variable (independent variable) on the dependent variable obtained by SPSS based on the conceptual framework and hypotheses that have been determined to prove some of the research hypotheses. The test results through regression analysis (beta test) on the dependent (y) and independent (X1) and (X2) variables, it was found that employee competence (X2) has a more dominant influence on employee performance (y) compared to the implementation of management information systems (X1). This is supported by the data on the employee competency count value (X2) which is higher than the implementation of the management information system (X1). However, the combination of the two is able to make a significant contribution to employee performance.

Keyword: Analisis Pengaruh Penerapan Sistem Informasi, Manajemen Diklat, Analisis Kinerja Pegawai

\section{PENDAHULUAN}

\section{Latar Belakang}

Salah satu faktor untuk mengembangkan sebuah Institusi yang baik adalah dengan meningkatkan kinerja pegawai. Beberapa hal yang dilakukan oleh banyak institusi seperti mengadakan pelatihan, memberikan reward untuk pegawai yang berprestasi, memanfaatkan teknologi dan informasi, serta masih banyak lagi.

Pemanfaatan teknologi dan informasi merupakan satu dari sekian banyak hal yang bisa dilakukan untuk mengoptimalkan kinerja pegawai. Hal ini kemudian diterapkan pada Politeknik Pelayaran Sorong dengan membangun sebuah sistem informasi Manajemen Diklat untuk memaksimalkan kinerja dan mempermudah pekerjaan pegawai, mulai dari pendaftaran peserta diklat, pengaturan jadwal diklat, serta analisis laporan pelaksanaan diklat yang sebelumnya dilakukan secara konvensional.

Untuk melihat hasil dari penerapan sistem informasi Manajemen Diklat, maka penelitian ini bertujuan untuk melakukan analisis terhadap pengaruh penerapan sistem informasi Manajemen Diklat dan kompetensi Pegawai terhadap kinerja pegawai pada Politeknik Pelayaran Sorong.

Analisis penerapan sistem informasi terhadap kompetensi dan kinerja pegawai telah dilakukan oleh beberapa peneliti, seperti penelitian yang dilakukan oleh (Yulianto \& Ginanjar, 2020) yaitu dengan menerapkan metode Servqual untuk membangun sistem informasi Manajemen Diklat untuk meningkatkan kualitas pelayanan informasi pada Balai Diklat Meteorologi.

Penelitian yang dilakukan oleh (Parikesit, 2019) pada Pusat Pembinaan, Pendidikan dan Pelatihan (Pusbindiklat) Badan Pengkajian dan Penerapan Teknologi (BPPT). Metode yang digunakan dalam analisis adalah Metode PIECES.

Penelitian ini melakukan analisis terhadap pelaksanaan diklat yang masih dilaksanakan secara manual dan belum terintegrasi dengan komputer, sehingga mengusulkan untuk merancang sistem informasi Manajemen Diklat.

Penelitian yang dilakukan oleh (Silalahi \& Saragih, 2019) dengan melakukan analisis terhadap pelaksanaan diklat pada Lembaga Pendidikan dan Pelatihan Madani (LP2M). Hasil penelitian menunjukkan bahwa sistem informasi manajemen dibutuhkan untuk mengelola berbagai kegiatan pada Lembaga tersebut. 


\section{TINJAUAN PUSTAKA}

\subsection{Sistem Informasi Manajemen}

Sistem berasal dari bahasa Yunani 'systema' yaitu himpunan bagian atau komponen yang saling berhubungan secara teratur dan merupakan suatu keseluruhan. bisa juga didefinisikan sekelompok elemen independent yang saling terkait dalam satu kesatuan. Sistem terdiri atas struktur dan proses. Struktur system merupakan unsurunsur yang membentuk sistem tersebut, sedangkan proses sistem menjelaskan cara kerja setiap unsur sistem dalam mencapai tujuan. Setiap sistem merupakan bagian dari sistem lain yang lebih besar dan terdiri atas berbagai sistem yang lebih kecil, yang disebut subsistem. Setiap sistem diciptakan untuk menangani sesuatu yang berulang-ulang atau yang secara rutin terjadi (Tyoso, 2016).

Menurut (Sutanta, 2003) sistem memiliki karakteristik sebagai berikut.

a. Komponen (components)

b. Batas (boundary)

c. Lingkungan (environments)

d. Penghubung/antarmuka (interface)

e. Masukan (input)

f. Pengolahan (processing)

g. Keluaran (output)

h. Sasaran (objectives) dan tujuan (goal)

i. Kendali (control)

j. Umpan balik (feed back)

Menurut O'Brien(2005) dalam buku

(Yakub, 2012), sistem informasi manajemen adalah sistem terpadu yang menyediakan suatu informasi untuk mendukung kegiatan operasional, manajemen, dan fungsi pengambilan keputusan dari suatu organisasi. Secara singkat, sebuah sistem informasi memproses data lalu mengubahnya menjadi suatu informasi.

Sistem informasi manajemen merupakan kombinasi antara people, hardware, software, communication network, dan data resources yang mengumpulkan, mengubah, dan menyebarkan informasi dalam suatu organisasi seperti yang terlihat pada gambar berikut:

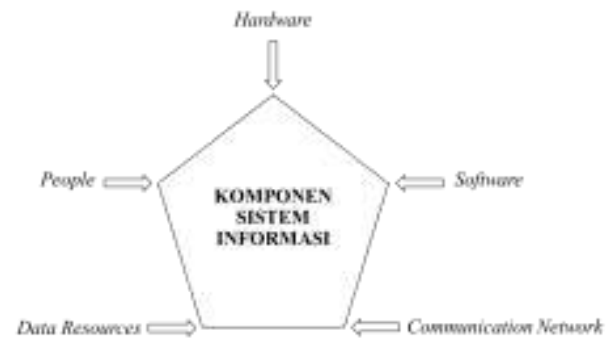

Gambar 1. Komponen Sistem Informasi

\subsection{Kompetensi Pegawai}

Menurut (Spencer etal., 1993), Kompetensi aalah bagian dalam dan selamanya ada pada kepribadian seseorang dan dapat memprediksikan tingkah laku dan performansi secara luas pada semua situasi dan pekerjaan.

Menurut Standar Kompetensi Kerja Nasional Indonesia (SKKNI) Sektor Jasa Bidang Jasa Administrasi Perkantoran (Republik Indonesia, 2007), kompetensi kerja merupakan kemampuan kerja setiap individu yang mencakup aspek pengetahuan, keterampilan dan sikap kerja sesuai dengan standar yang ditetapkan.

Dapat disimpulkan bahwa kompetensi pegawai merupakan tingkah laku atau performansi yang melekat pada masing-masing individu (pegawai) yang dapat diprediksi pada berbagai tugas pekerjaan.

Kompetensi Pegawai Menurut (Spencer et al., 1993), Kompetensi adalah bagian dalam dan selamanya ada pada kepribadian seseorang dan dapat memprediksikan tingkah laku dan performansi secara luas pada semua situasi dan pekerjaan.

Menurut Standar Kompetensi Kerja Nasional Indonesia (SKKNI) Sektor Jasa Bidang Jasa Administrasi Perkantoran (Republik Indonesia, 2007), kompetensi kerja merupakan kemampuan kerja setiap individu yang mencakup aspek pengetahuan, keterampilan dan sikap kerja sesuai dengan standar yang ditetapkan.

Dapat disimpulkan bahwa kompetensi pegawai merupakan tingkah laku atau performansi yang melekat pada masing-masing individu (pegawai) yang 
dapat diprediksi pada berbagai tugas pekerjaan.

\subsection{Kinerja Pegawai}

Menurut (Prawirosentono, 1999) Kinerja adalah hasil kerja yang dapat dicapai oleh seseorang atau sekelompok orang dalam suatu organisasi sesuai dengan wewenang dan tangung jawab masing-masing, dalam rangka upaya mencapai tujuan organisai bersangkutan secara legal, tidak melanggar hukum dan sesuai dengan moral dan etika.

Menurut (Suryani et al., 2020) kinerja karyawan sering juga disebut prestasi kerja. Yaitu berdasar pada perilaku nyata yang ditampilkan setiap karyawan sebagai prestasi kerja yang dihasilkannya.

\section{METODE PENELITIAN}

\subsection{Kerangka Konseptual Penelitian}

Berdasarkan tinjauan pustaka yang telah dijelaskan sebelumnya, maka bagan kerangka konseptual penelitian sebagai berikut:

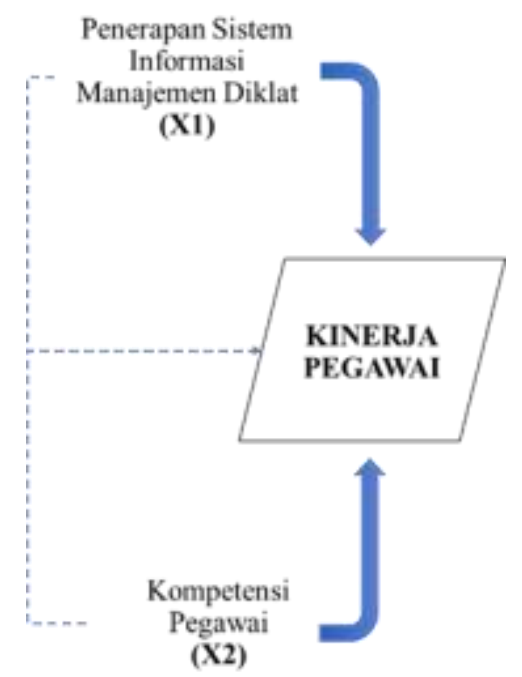

Gambar 2. Kerangka Konseptual Penelitian

\subsection{Rancangan Penelitian}

penelitian ini merupakan explanatif research dimana dilakukan suatu pengamatan yang menjelaskan hubungan antara variabel-variabel menggunakan pengujian hipotesis tanpa memberikan perlakuan. Sampel penelitian ini menggunakan pegawai di Politeknik Pelayaran Sorong yang berjumlah 20 orang.

Data yang digunakan adalah data primer dengan melakukan observasi, wawancara, dan kuesioner. Seluruh pertanyaan dijawab secara langsung dan panduan penelitian untuk memperoleh jawaban dari responden.

\subsection{Analisis Data Penelitian}

Pada penelitian ini, analisis data menggunakan regresi linier berganda yang dioleh dengan SPSS. Berdasarkan kerangka konseptual dan hipotesis yang telah ditentukan, maka dilakukan proses pengujian data yang selanjutkan dianalisis menggunakan regresi linier berganda yang dimaksudkan untuk membuktikan sebagian hipotesis penelitian yang telah ditentukan. Model dari analisis regresi linier berganda pada penelitian ini adalah sebagai berikut :

$$
\begin{gathered}
\mathrm{Y}=\mathrm{a}+\mathrm{b} \_1 \mathrm{X} \_1+\mathrm{b} \_2 \mathrm{X} \_2+\mathrm{e} \\
\text { Dimana } \\
\mathrm{Y}=\text { Variabel Dependen } \\
\mathrm{X} \_1, \mathrm{X} \_2=\text { Variabel Independen } \\
\mathrm{a}=\text { Konstanta } \\
\mathrm{b} \_1, \mathrm{~b} \_2==\text { Koefisien regresi } \\
\mathrm{e}=\text { Standar Error }
\end{gathered}
$$

Dengan kriteria Ho:b_1-b_8=0 Tidak ada pengaruh antara variabel independen terhadap variabel dependen. Hi:b_1-b_8 80 Adanya pengaruh antara variabel independen terhadap variabel dependen.

\section{HASIL DAN PEMBAHASAN}

Keseluruhan data responden digunakan sebagai inputan model untuk proses uji validitas yang selanjutnya akan dilakukan analisis menggunakan regresi linier berganda. Langkah awal, keseluruhan data diinput dalam bentuk tabel menggunakan aplikasi MS excel. Selanjutnya, data tersebut diolah menggunakan software SPSS versi 25 dengan Teknik analisis regresi linier berganda. Hasil perhitungan dilihat pada tabel berikut : 
Tabel 1. Hasil perhitungan regresi linear berganda

\begin{tabular}{|l|l|l|}
\hline \multicolumn{1}{|c|}{ Variable } & \multicolumn{1}{|c|}{$\begin{array}{c}\text { Koef. } \\
\text { Regresi }\end{array}$} & Std Error \\
\hline $\begin{array}{l}\text { Penerapan } \\
\text { Sistem } \\
\text { informasi } \\
\text { Manajemen }\end{array}$ & 0,649 & 0,41562 \\
\hline $\begin{array}{l}\text { Kompetensi } \\
\text { Pegawai }\end{array}$ & 0,662 & 0,33574 \\
\hline Konstanta & 0.2391 & 5,2457856 \\
\hline
\end{tabular}

Berdasarkan hasil yang didapatkan pada table 1, penerapan sistem informasi manajemen memiliki nilai koefisien 0,649 dengan asumsi nilai variable lain konstan didapatkan peningkatan \pm 1 point yang mengidentifikasikan adanya peningkatan kinerja pegawai sekitar $64 \%$. Sedangkan kompetensi pegawai memilki nilai koefisien 0,662 dengan asumsi nilai variable lain konstan didapatkan peningkatan \pm 1 point yang mengidentifikasikan adanya peningkatan kinerja pegawai sekitar $66 \%$.

Penelitian ini juga melakukan pengujian hipotesis yang dibagi kedalam 4 bagian yaitu penerapan sistem informasi manajemen berpengaruh signifikan terhadap kinerja pegawai, kompetensi pegawai berpengaruh signifikan terhadap kinerja pegawai, penerapan sistem informasi manajemen dan kompetensi pegawai secara simultan berpengaruh signifikan terhadap kinerja pegawai, dan kompetensi pegawai berpengaruh dominan terhadap kinerja pegawai (Suyitno, 2017).

4.1 Penerapan sistem informasi manajemen berpengaruh signifikan terhadap kinerja pegawai

Hasil pengujian melalui analisis secara partial terhadap variabel dependen (y) dan independen (X1) tersebut didapatkan bahwa penerapan sistem informasi menajemen (X1) memberikan pengaruh yang signifikan terhadap kinerja pegawai $(y)$. Nilai signifikansi $t=0,0000$, nilai regresi $\beta=0,649$, dan koefisien determinansi $\quad r^{2}=0,357$. Dapat disimpulkan variabel independent $(X 1)$ memberikan kontribusi terhadap variabel dependen $(y)$ sebesar $35,7 \%$ dan $64,3 \%$ dikontribusikan variabel lain.

\subsection{Kompetensi pegawai berpengaruh signifikan terhadap kinerja pegawai}

Hasil pengujian melalui analisis regresi sederhana (uji t) terhadap variabel dependen (y) dan independen (X2) tersebut didapatkan bahwa kompetensi pegawai (X2) memberikan pengaruh yang signifikan terhadap kinerja pegawai (y). Nilai signifikansi $\mathrm{t}=0,0000$, nilai regresi $\beta=0,662$, dan koefisien determinansi $\mathrm{r}^{\wedge} 2=0,593$. Dapat disimpulkan variabel independent (X2) memberikan kontribusi terhadap variabel dependen (y) sebesar $59,3 \%$ dan $40,7 \%$ dikontribusuikan variabel lain.

\subsection{Penerapan sistem informasi manajemen} dan kompetensi pegawai secara simultan berpengaruh signifikan terhadap kinerja pegawai

Hasil pengujian melalui analisis regresi berganda (uji F) terhadap variabel dependen $(y)$, independen $(X 1)$ dan independen (X2) tersebut didapatkan bahwa penerapan sistem informasi manajemen (X1) dan kompetensi pegawai $(X 2)$ memberikan pengaruh yang signifikan terhadap kinerja pegawai $(y)$. Nilai signifikansi $\mathrm{F}=0,0000$ dan koefisien determinansi $r^{2}=0,664$. Dapat disimpulkan variabel independent (X1) dan (X2) memberikan kontribusi terhadap variabel dependen $(y)$ sebesar $66,4 \%$ dan $33,6 \%$ dikontribusuikan variabel lain.

4.4 Kompetensi pegawai berpengaruh dominan terhadap kinerja pegawai

Hasil pengujian melalui analisis regresi (uji beta) terhadap variabel dependen (y) dan independent (X1) dan 
(X2) tersebut didapatkan bahwa kompetensi pegawai (X2) memberikan pengaruh yang lebih dominan terhadap kinerja pegawai (y) dibandingkan dengan penerapan sistem informasi manajemen (X1). Hal ini didukung dengan data nilai hitung kompetensi pegawai (X2)yang lebih tinggi dibandingkan penerapan sistem informasi manajemen (X1).

Berdasarkan hasil analisis keseluruhan hipotesis menunjukkan bahwa pegawai memiliki pengetahuan tentang tupoksinya dan keterampilan sehingga kondisi kompetensi pegawai 'baik' dan memenuhi standar kerja dari Politeknik Pelayaran Sorong.

\section{SIMPULAN DAN SARAN}

\subsection{Simpulan}

Dari hasil análisis, maka diperoleh kesimpulan bahwa penerapan sistem informasi menajemen memberikan pengaruh yang signifikan terhadap kinerja pegawai sebesar $35,7 \%$ dan $64,3 \%$ dikontribusikan variabel lain. Kompetensi pegawai berpengaruh signifikan terhadap kinerja pegawai sebesar 59,3\% dan $40,7 \%$ dikontribusuikan variabel lain.

Penerapan sistem infromasi manajemen dan kompetensi pegawai secara simultan berpengaruh signifikan terhadap kinerja pegawai sebesar $66,4 \%$ dan 33,6\% dikontribusuikan variabel lain. Hasil pengujian melalui analisis regresi (uji beta) terhadap variabel dependen (y) dan independent (X1) dan (X2) tersebut didapatkan bahwa kompetensi pegawai (X2) memberikan pengaruh yang lebih dominan terhadap kinerja pegawai (y) dibandingkan dengan penerapan sistem informasi manajemen (X1).

Hal ini didukung dengan data nilai hitung kompetensi pegawai (X2) yang lebih tinggi dibandingkan penerapan sistem informasi manajemen (X1). Namun kombinasi keduanya mampu memberikan kontribusi yang cukup besar terhadap kinerja pegawai.

\subsection{Saran}

Penelitian selanjutnya diharapkan dapat menambah beberapa jenis variabel lain untuk menganalisis kinerja pegawai pada Politeknik Pelayaran Sorong.

\section{Daftar Pustaka}

Parikesit, R. B. (2019). Perancangan Sistem Informasi Manajemen Diklat Pada Badan Pengkajian dan Penerapan Teknologi (BPPT), Jakarta Pusat. JUKOMIKA (Jurnal IImu Komputer dan Informatika), 2(4), 130-137.

Prawirosentono, S. (1999). Kebijakan Kinerja Karyawan (Yogyakarta).

Republik Indonesia. (2007). Standar Kompetensi Kerja Nasional Indonesia (SKKNI) Sektor Jasa Bidang Jasa Administrasi Perkantoran Perkantora.

Silalahi, M., \& Saragih, S. P. (2019). Sistem Informasi Manajemen Lembaga Pendidikan dan Pelatihan Madani (LP2M) dengan Metode Extreme Programming. Journal of Applied Informatics and Computing (JAIC), 3(2), 107113. https://doi.org/10.30871/jaic.v3i2.1643

Spencer, Lely, M., \& Signe. (1993). Competence At Work, Models for Superior Performance. John Wiley \& Sons Inc.

Suryani, N. K., Sugianingrat, I. A. P. W., \& Laksemini, K. D. I. S. (2020). Kinerja Sumber Daya Manusia: Teori, Aplikasi dan Penelitian. Nilacakra.

Sutanta, E. (2003). Sistem Informasi

Manajemen (Yogyakarta). Graha Ilmu. 
Suyitno, S. (2017). Analisis Penerapan Sistem Informasi Manajemen dan Kompetensi Pegawai Serta Pengaruhnya terhadap Kinerja Pegawai. Journal of Applied Business Administration, 1(2), 270-279.

Tyoso, J. S. P. (2016). Sistem Informasi Manajemen. Deepublish.

Yakub. (2012). Pengantar sistem informasi (1st ed., Vol. 1). Yogyakarta Graha IImu 2012.

Yulianto, E., \& Ginanjar, A. (2020).

Pembangunan Sistem Informasi Manajemen

Diklat Menggunakan Metode Servqual Dalam

Upaya Meningkatkan Kualitas Pelayanan Informasi (Studi Kasus: Balai Diklat Metrologi). Media Jurnal Informatika, 11(1), 8-19.

https://doi.org/10.35194/mji.v11i1.883 